\title{
PENTINGNYA PENGURUSAN HAK KEKAYAAN INTELEKTUAL BAGI PRODUK-PRODUK LITBANGYASA ${ }^{1}$
}

\author{
Oleh: Dewi Anggraeni \\ Konsultan HKI Terdaftar 424-2010 \\ Dosen Magister Hukum Universitas Pamulang \\ Email: Dewifhunpam@yahoo.com
}

\begin{abstract}
Abstrak
Hak kekayaan intelektual ini merupakan hasil olah piker atau kreatifitas manusia yang menghasilkan suatu ciptaan dibidang seni, sastra, ilmu pengetahuan serta teknologi di dalamnya yang mempunyai manfaat ekonomi, jadi penting sekali karena suatu invensi yang tidak mempunyai manfaat ekonomi itu tidak dapat dikatakan sebagai suatu (Intellectual Property). Pentingnya pendaftaran hak kekayaan intelektual di lembaga penelitian, pengembangan dan Perekayasaan (Litbangyasayasa) untuk mengetahui sejauh mana kompetensi peneliti balai Litbangyasayasa memahami dan menerapkan paten. Pada umumnya sudah mengenal paten, namun pemahaman teknis akan jangka perlindungan paten, Kriteria invensi yang dapat memperoleh paten masih relative kurang. Sebagian peneliti melakukan penelitian atas dasar tugas dari atasan, belum menunjukkan keseriusan untuk menghasilkan sesuatu invensi baru dan mengandung unsur inventif atau kurangnya kepedulian atas pentingnya mengajukan permohonan pendaftaran atas invensi tersebut.
\end{abstract}

Kata Kunci: Hak Kekayaan Intelektual, Produk-Produk Litbangyasa

\begin{abstract}
This intellectual property is the result of a thought to carry away or human creativity that produced a work in art, literature, science and technology in it that has economic benefits, so it's important for an invention that has no economic benefit can not be regarded as a (Intellectual Property). The importance of registration of intellectual property rights in research institutes, development and Engineering (Litbangyasayasa) to determine the extent of the competence centers Litbangyasayasa researchers understand and apply patent. Already generally familiar with patents, but technical understanding will term patent protection, the invention criteria can obtain a patent is still relatively lacking. Most researchers conducted research on the basic job of the boss, do not indicate the seriousness of the invention to produce something new and inventive contain elements or lack of awareness on the importance of applying for registration of an invention.
\end{abstract}

Keywords: Intellectual Property Rights, Products Litbangyasa

\section{A. Latar Belakang}

Indonesia kini dan mendatang harus berubah, dari sekian banyaknya perubahan yang harus dilakukan, perubahan yang menyangkut perlindungan terhadap informasi

\footnotetext{
${ }^{1}$ Naskah diterima tanggal 2 Januari 2016, direvisi: 23 Maret 2016, disetujui untuk terbit 28 Mei 2016 dalam Volume 3 No. 1 Juli 2016
} 
dan knowledge tidak boleh dilupakan. Hal ini tidak saja karena informasi dan knowledge merupakan kekayaan intelektual (Intellectual Property) yang memiliki nilai-nilai moral (moral values). Melainkan juga memiliki nilai ekonomi (economic values). Oleh karena itu, proses perolehan dan pemilikan Hak Kekayaan Intelektual (HKI) sebagai wujud perlindungan terhadap kekayaan intelektual, mutlak harus didukung, difasilitasi dan dipermudah oleh semua pihak.

Dengan adanya dukungan, fasilitasi dan kemudahan tersebut, tidak saja jumlah pemilikan HKI semakin besar dan berkualitas, namun yang lebih penting lagi dapat mencerminkan posisi kemajuan iptek nasional disatu pihak dan sebagai indicator kemajuan ekonomi dan kesejahteraan masyarakat dipihak lain. Terlebih-lebih lagi dengan adanya kebebasan masuknya barang dan jasa sebagai akibat hilangnya batasbatas Negara (globalisasi). Kondisi ini menghasilkan persaingan yang semakin ketat di berbagai lini kehidupan social-ekonomi dan budaya sehingga berpengaruh terhadap daya saing dan daya tahan serta kesinambungan pembangunan nasional.

Berbagai usaha pemerintah telah dilakukan untuk meningkatkan pertumbuhan penerapan hak kekayaan intelektual dilingkungan lembaga penelitian, pengembangan dan perekayasaan (Litbangyasayasa), perguruan tinggi dan industri, tetapi disadari bahwa hal itu belum mencapai hasil yang menggembirakan. Rendahnya jumlah hak yang terdaftar menunjukkan masih kurangnya perhatian para peneliti dan perekayasa Indonesia untuk menghasilkan penemuan-penemuan baru.

Hak kekayaan intelektual (HKI) disebut juga hak atas kekayaan intelektual (HAKI) atau hak milik intelektual (HMI), merupakan padanan dari bahasa inggris Intellectual Property Rights (IPR), kata intelektual mencerminkan bahwa obyek kekayaan intelektual adalah kecerdasan, daya pikir atau produk pemikiran manusia (the creations of the human mind).

HKI adalah instrument hukum yang memberikan perlindungan hak pada seseorang atau organisasi atas segala hasil kreativitas dan perwujudan karya intelektual serta memberikan hak kepada pemilik untuk menikmati keuntungan ekonomi dari kepemilikan hak tersebut. Hasil karya intelektual tersebut dalam praktek dapat berwujud penemuan di bidang teknologi atau ciptaan dibidang lain. ${ }^{2}$

\footnotetext{
${ }^{2}$ Web.mit.edu/ipc/www/pubs/articles/chakrabarti.pdf
} 
Sesuai ketentuan perundang-undangan, para pemilik HKI berhak untuk menggunakan, memperbanyak, mengumumkan, memberikan izin kepada pihak lain untuk memanfaatkan hak nya tersebut melalui lisensi atau pengalihan; termasuk untuk melarang pihak lain menggunakan, memperbanyak dan/atau mengumumkan hasil karya intelektualnya tersebut.

Dari sudut pandang lain, HKI merupakan hak monopoli yang diberikan kepada pemilik hak, sesuai dengan batasan pada peraturan perundang-undangan yang berlaku. Berbagai faktor penyebab rendahnya jumlah hak paten dapat ditelusuri dari berbagai kemungkinan. Sosialisasi yang kurang efektif di kalangan lembaga litbangyasayasa, industri dan perguruan tinggi, masih rendahnya penegakkan HKI lainya. Dan masih rendahnya kesadaran nasional terhadap perlunya penciptaan inovasi yang akan memperkuat iptek nasional dan daya saing industri. ${ }^{3}$

HKI semakin menjadi isu penting dalam hubungan ekonomi internasional, sejalan dengan pertumbuhan pengakuan HKI Negara-negara yang tidak memiliki perlindungan yang memadai terhadap HKI akan mengalami kesulitan dalam perdagangan, karena tidak terjaminnya persaingan yang sehat dan rendahnya kepercayaan internasional untuk berinvestasi.

Mengingat hal itu, usaha sosialisasi perlu diperbanyak di berbagai lapisan masyarakat. Sosialisasi HKI harus dilakukan pada semua kalangan terkait seperti mahasiswa, peneliti, pemerintah, masyarakat umum, sector industri, aparat penegak hukum, maupun lingkungan media yang berfungsi menyebarluaskan pemberitaan agar menjangkau banyak lapisan.

Tujuan penulisan ini ialah untuk mengetahui upaya meningkatkan pemahaman tentang pentingnya pendaftaran hak kekayaan intelektual di PUSLITBANGYASA.

\section{B. Pembahasan}

\section{Jenis-jenis HKI}

Secara umum HKI dibagi dalam dua kategori, yaitu : (1) Hak Cipta dan (2) Hak Kekayaan Industri. Hak cipta adalah hak eksklusif bagi pencipta atau penerima hak untuk mengumumkan atau memperbanyak ciptaanya atau memberikan izin untuk itu

\footnotetext{
${ }^{3}$ www.ristek.go.id/indexphp/module/news diakses 13 Nov 2015
} 
dengan tidak mengurangi pembatasan-pembatasan menurut peraturan perundangundangan yang berlaku. Sedangkan hak kekayaan industri meliputi : paten, merek, desain industri, desain tata letak sirkuit terpadu, rahasia dagang dan varietas tanaman. Berikut adalah penjelasan tentang jenis-jenis HKI tersebut.

a) Hak Cipta (copyright), adalah suatu hak yang diberikan pada pencipta atas karya literature dan artistic mereka. Tujuan utamanya untuk memberikan perlindungan atas hak cipta dan untuk mendukung serta memberikan penghargaan atas buah kreatifitas.(UU No.28 tahun 2014).

b) Paten (patent), adalah hak eksklusif yang diberikan Negara kepada inventor atas hasil invensinya di bidang teknologi, untuk selama waktu tertentu melaksanakan sendiri invensinya tersebut atau memberikan persetujuannya kepada pihak lain untuk melaksanakannya (UU No.14 tahun 2001).

c) Merk Dagang (Trademark), adalah tanda yang berupa gambar, nama, kata, huruf-huruf, angka-angka, susunan warna, atau kombinasi dari unsur-unsur tersebut yang memiliki daya pembeda dan digunakan dalam kegiatan perdagangan barang atau jasa (UU No.15 tahun 2001).

d) Desain Industri (industrial design), adalah suatu kreasi tentang bentuk, konfigurasi atau komposisi garis atau warna, atau garis dan warna atau gabungan daripadanya yang berbentuk tiga dimensi atau dua dimensi yang memberikan kesan estetis dan dapat diwujudkan dalam pola tiga dimensi atau dua dimensi serta dapat dipakai untuk menghasilkan suatu produk, barang, komoditas industri, atau kerajinan tangan (UU No.31 tahun 2000).

e) Sirkuit terpadu, adalah suatu produk dalam bentuk jadi atau setengah jadi, yang di dalamnya terdapat berbagai elemen dan sekurang-kurangnya satu dari elemen tersebut adalah elemen aktif, yang sebagian atau seluruhnya saling berkaitan serta dibentuk secara terpadu di dalam sebuah bahan semikonduktor yang dimaksudkan untuk menghasilkan fungsi elektronik (UU No.32 tahun 2000).

f) Rahasia Dagang (trade secret), adalah informasi yang tidak diketahui oleh umum dibidang teknologi dan/atau bisnis, mempunyai nilai ekonomi karena berguna dalam kegiatan usaha, dan dijaga kerahasiaanya oleh pemilik rahasia dagang. Berbeda dari jenis HKI lainnya, rahasia dagang tidak dipublikasikan ke 
public. Rahasia dagang dilindungi selama informasi tersebut tidak “dibocorkan” oleh pemilik rahasia dagang.

g) Perlindungan Varietas Tanaman, didefinisikan sebagai sekelompok tanaman dari suatu jenis atau spesies yang ditandai oleh bentuk tanaman, pertumbuhan tanaman, daun, bunga, buah, biji dan ekspresi karakteristik genotipe atau kombinasi genotipe yang dapat membedakan dari jenis atau spesies yang sama oleh sekurang-kurangnya satu sifat yang menentukan dan apabila diperbanyak tidak mengalami perubahan (UU No.29 tahun 2000).

\section{Pemanfaatan HKI}

Sesuai dengan esensi dari sistem HKI yang merupakan "penghargaan” bagi orang-orang yang kreatif, inventif dan inovatif, maka pemanfaatan HKI merupakan bagian penting dalam sistem HKI. Salah satu esensi utama yang terkandung di dalam sistem HKI adalah nilai ekonomi yang terkandung didalamnya, terutama selama dalam masa perlindungan efektif. Seseorang atau lembaga yang memiliki HKI akan mendapatkan hak untuk menentukan bentuk pemanfaatan dari HKI yang dimilikinya, termasuk target wilayah, target konsumen dan sebagainya. Hal ini merupakan bagian dari penghargaan pemberian “eksklusif” yang terkandung dalam sistem HKI bagi pemiliknya.

Banyak pihak mengatakan bahwa pemanfaatan kekayaan intelektual hasil kegiatan perguruan tinggi berbasiskan sistem HKI baru dapat dilakukan apabila kekayaan intelektual tersebut telah dilindungi atau telah mendapatkan sertifikat atau granted, missal telah memperoleh sertifikat paten, hak cipta, merek atau yang lainnya. Secara prinsip hal tersebut memang benar, akan tetapi mengingat lamanya proses permohonan perlindungan, maka ada kalanya si pemohon atau pemilik harus dapat menyikapi dengan baik dalam upaya pemanfaatannya. ${ }^{4}$

Dari berbagai UU dibidang HKi (UU paten, desain industry dan sebagainya) dinyatakan bahwa dimungkinkanya adanya pengalihan hak dan lisensi. Pengalihan hak dapat terjadi karena pewarisan, hibah, wasiat, perjanjian tertulis atau sebab-sebab lain.

\footnotetext{
4 Ditjen HKI, Prosedur Permohonan Paten http://www.dgip.go.id/ ebscript/ publicportal.cgi, diakses 9 Nov 2015
} 
Lisensi terjadi karena pengalihan berdasarkan perjanjian lisensi. Berdasarkan hal tersebut, maka pemanfaatan HKI dapat dilakukan sendiri oleh pemilik atau melimpahkannya atau memberikan ijinnya kepada pihak lain.

\section{Pemahaman Paten}

Penguasaan teknologi merupakan kunci keberhasilan suatu bangsa, hal ini dapat diketahui dari keberhasilan jepang, korea selatan dan Taiwan yang tumbuh dari Negara berkembang menjadi Negara maju, walaupun tidak memiliki sumber daya alam yang mencukupi. Negara-negara tersebut melakukan peningkatan kegiatan litbangyasa untuk memperoleh teknologi terbaik dan kompetitif.

Pengembangan dan penguasaan teknologi tidak akan mungkin tercapai dengan baik tanpa adanya dukungan budaya kreatif dan inovatif dari sebagian besar masyarakat, sehingga kegiatan penelitian dan pengembangan dapat menghasilkan teknologi terbaik dan kompetitif. Budaya kreatif dan inovatif hanya akan tumbuh dan berkembang dengan subur dalam lingkungan masyarakat yang menghargai menegakkan dan melindungi HKI.

Bidang dalam HKI yang berkaitan dengan teknologi adalah paten, hak paten memberikan hak eksklusif kepada inventor (penemu) untuk memperoleh manfaat ekonomi dari invensinya di bidang teknologi selama jangka waktu tertentu. Hak eksklusif ini diberikan untuk memberikan penghargaan kepada inventor, karena untuk menghasilkan suatu invensi yang layak diberi paten, inventor telah menghabiskan banyak waktu, biaya, tenaga, dan pikiran dalam melakukan penelitian dan pengembangan, sehingga memacunya terus berkarya. Hak eksklusif ini juga mendorong investasi karena adanya kesempatan untuk mengembalikan biaya yang dikeluarkan dalam mengembangkan invensi.

Pemahaman tentang paten sangat diperlukan oleh para peneliti atau innovator, selain untuk mengetahui hak yang akan diperolehnya juga perlunya menghindari pelanggaran atas hak kekayaan intelektual pihak lain.

\section{Informasi Paten}

Dalam mengembangkan suatu kegiatan paten sebaiknya dimulai dengan mencari informasi tentang paten yang sudah ada ataupun jenis teknologi yang belum 
dikembangkan patennya. Informasi paten merupakan kumpulan publikasi informasi teknik yang ditemukan dalam dokumen paten, yaitu dokumen permohonan paten dan dokumen yang telah diberi paten, beserta informasi hukum terkait.

Berdasarkan sistem paten yang berlaku secara universal, setiap dokumen permohonan paten dan dokumen yang telah diberi paten harus dipublikasikan kepada masyarakat. Berbeda dengan kumpulan publikasi informasi teknik berupa dokumen non-paten yang biasanya termuat dalam jurnal ilmiah dan database yang hanya bisa diakses oleh masyarakat secara bebas pada hampir semua kantor paten di dunia.

Informasi paten dapat membantu membuat keputusan ketika memilih strategi untuk meneliti atau mengembangkan produk baru. Jika ada masalah teknis, tidak ada cara yang lebih baik untuk menemukan apa solusi yang ada dengan melihat informasi paten lainnya.

Rincian teknis dari penelitian yang dilakukan oleh pihak lain muncul pertama dalam dokumen paten, jauh sebelum produk tersebut mencapai pasar, informasi paten dapat digunakan untuk mengidentifikasi paten yang tidak lagi berlaku dan dapat bebas digunakan. Melalui informasi paten, innovator juga dapat memastikan tidak akan terjadi pelanggaran terhadap paten lain sebelum mengeluarkan sebuah produk baru.

\section{Kriteria Pemberian Paten}

Paten hanya dapat diberikan untuk invensi yang memenuhi kriteria baru, mengandung langkah inventif serta dapat diterapkan dalam industry, sebagaimana tertuang dalam UU No.14 tahun 2001 tentang paten pasal 2 ayat (1). Invensi dianggap baru apabila pada tanggal penerimaan, invensi tersebut tidak sama dengan teknologi yang diungkapkan sebelumnya.

Suatu invensi “tidak sama” adalah bukan sekedar beda, melainkan dilihat apakah ciri teknis invensi tersebut sama atau tidak sama dengan cirri teknis invensi sebelumnya. Sedangkan arti "teknologi yang telah diumumkan, baik di Indonesia maupun diluar negeri dalam suatu tulisan, uraian lisan, peragaan atau dengan cara lain yang memungkinkan seorang ahli untuk melaksanakan invensi tersebut, sebelum tanggal penerimaan atau tanggal prioritas.

Baru berarti bahwa teknologi yang diajukan harus berbeda dengan teknologi sebelumnya (state of the art). Yang dapat menggugurkan kebaruan suatu permohonan 
paten mencakup dokumen paten dan dokumen non-paten yang telah diumumkan atau ditempatkan pada sarana apapun yang dapat diakses masyarakat dimana pun diseluruh dunia dan dalam bahasa apapun. Teknologi yang diungkapkan sebelumnya tersebut mencakup dokumen permohonan paten yang diajukan di Indonesia yang dipublikasikan pada atau setelah tanggal penerimaan atau tanggal prioritas dokumen permohonan paten yang pemeriksaan substantinya sedang dilakukan. Ketentuan ini dimaksudkan untuk memecahkan permasalahan yang muncul akibat adanya invensi yang sama yang diajukan oleh pemohon yang berbeda dalam waktu yang tidak bersamaan (conflicting application).

Tanggal prioritas adalah tanggal penerimaan di Negara asal dengan ketentuan kedua Negara merupakan anggota konvensi Paris atau WTO serta permohonan paten di Negara tujuan diajukan paling lama 12 bulan sejak tanggal prioritas. Dalam pasal 2 UU paten dinyatakan bahwa suatu invensi mengandung langkah inventif jika invensi tersebut bagi seseorang yang mempunyai keahlian tertentu di bidang teknik merupakan hal yang tidak dapat diduga sebelumnya. Penilaian ini harus dilakukan dengan memperhatikan keahlian yang ada pada saat permohonan paten diajukan atau yang telah ada pada saat diajukan permohonan paten pertama di Negara asal yang merupakan anggota konvensi Paris atau WTO jika tanggal prioritas diakui. ${ }^{5}$

Pengertian mengenai invensi yang dapat diterapkan dalam industry termuat dalam penjelasan pasal 5 UU yang sama, yaitu jika invensi tersebut dapat dilaksanakan dalam industry seperti yang diuraikan dalam permohonan paten. Apabila invensi tersebut berupa produk, harus dapat dibuat secara missal atau berulang-ulang dengan kualitas yang sama, sedangkan apabila invensi tersebut berupa proses, harus dapat dijalankan atau digunakan dalam praktek.

Menurut pasal 7 UU No.14 tahun 2001, selain memenuhi kriteria pemberian paten, suatu invensi hanya dapat diberi paten jika bukan merupakan invensi tentang :

1) Proses atau produk yang pengumuman dan penggunaan atau pelaksanaannya bertentangan dengan peraturan perundang-undangan yang berlaku, moralitas agama, ketertiban umum, atau kesusilaan;

${ }^{5}$ European Patent Office, Intellectual Property Watch, http://www.ipwatch.org/ weblog.epo_looks_to_future_technologies_leadership_change diakses 9 Nov 2015 
2) Metode pemeriksaan, perawatan, pengobatan dan/atau pembedahan yang diterapkan terhadap manusia dan/atau hewan;

3) Teori dan metode di bidang ilmu pengetahuan dan matematika;atau

a. Semua mahluk hidup, kecuali jasad renik;

b. Proses biologis yang esensial untuk memproduksi tanaman atau hewan, kecuali proses non-biologis atau proses mikrobiologis.

UU No.14 tahun 2001 juga menyediakan bentuk perlindungan yang disebut paten sederhana, terbatas pada alat atau produk yang berwujud (tangible). Menurut pasal 6 dan pasal 105, paten sederhana hanya dapat diberikan untuk invensi yang baru dan mempunyai nilai kegunaan praktis disebabkan oleh bentuk, konfigurasi,konstruksi, komponennya serta dapat diterapkan dalam industri.

Alat atau produk tersebut bukan hanya sekedar berbeda cirri teknisnya tetapi harus memiliki fungsi/kegunaan yang lebih praktis dari invensi sebelumnya, seperti ,manfaat ekonomis (lebih murah dari sebelumnya), penggunaannya lebih mudah, teknologinya tepat guna, atau produknya banyak digunakan dalam kehidupan seharihari. Criteria nilai kegunaan praktis ini pada dasarnya sama dengan criteria langkah inventif tetapi dengan tingkat kompleksitas yang lebih rendah.

\section{Kebaruan (Novelty)}

Penemuan yang dimintakan paten adalah penemuan yang baru. Sebagai lazimnya di dalam sistem paten, penemuan disebut baru bila ia tidak mengandung bagian teknologi yang ada pada saat ini (state of the art). Pemakaian atau cara lainnya sebelum penemuan itu diajukan ke kantor HKI. State of the art diartikan secara luas tidak ada batas geografi, bahasa atau cara yang dipakai sehingga tersedia untuk umum, juga tidak ada batas usia dokumen atau sumber informasi lainnya. Tetapi karena state of the art yang diketahui oleh pemeriksa hanya berupa dokumen-dokumen yang tercantum dalam laporan penelusuran, kemudian bagaimana dengan dokumen yang diketahui umum lainnya. Uraian dalam bentuk tertulis, yaitu dokumen harus dianggap milik untuk umum, jika pada tanggal yang dimaksudkan memungkinkan anggota masyarakat memperoleh pengetahuan dari dokumen dan tidak ada larangan untuk menggunakan atau melaksanakan pengetahuan itu. Dokumen-dokumen itu disebut dalam laporan penelusuran yang ada hubungannya terhadap penemuan diklasifikasikan sebagai 
relevan, ada hubungan tidak langsung dan sebagainya. Jika pengetahuan itu berupa uraian lisan di depan umum sebelum tanggal diajukannya paten yang bersangkutan maka uraian itu pertama kali dianggap masuk dalam state of the art, orang yang mengajukan permintaan paten dapat menyanggahnya atau meminta buktinya pada pemeriksa paten bila laporan pemeriksa paten menyatakan state of the art dalam bentuk lisan sebelumnya.

\section{Langkah Inventif}

Suatu penemuan mengandung langkah inventif, jika penemuan tersebut bagi seorang yang mempunyai keahlian biasa mengenai tehnik merupakan hal yang tidak dapat di duga sebelumnya. Penilaian mengandung langkah inventif dalam pemeriksaan paten merupakan bagian yang tersulit dan seringkali membawa seorang pemeriksa paten diambang keragu-raguan. Sehingga tidak aneh bila pada tahap ini seorang pemeriksa paten melakukan pemeriksaan ulang atas hasil yang pernah dilakukannya. Kebaruan merupakan sesuatu yang harus ada sebelum langkah inventif dapat dinilai, artinya tanpa kebaruan tidak ada penilaian langkah inventif. Pernyataan di atas menunjukkan bahwa dalam proses mempertimbangkan langkah inventif tidak memasukkan dokumen yang diajukan sesudahnya atau yang dipublikasikan sesudahnya. ${ }^{6}$

Beberapa hal yang dapat meniadakan langkah inventif antara lain (1) bila formulasi suatu ide atas penyelesaian suatu masalah akan menghasilkan suatu yang dapat di duga (2) bila penyelesaian masalah yang telah diketahui sebelumnya, dan (3) bila hasil suatu pengamatan telah sampai pada penyebab pokok masalah.Dalam menentukan sumbangan dari penemuan tertentu untuk menetapkan adanya langkah inventif, maka pemeriksa paten tidak akan menganggap uraian atau pernyataan dalam dokumen paten serta klaimnya itu benar adanya, kecuali bila orang yang mengajukan permintaan paten kemudian menyatakan ada kesalahan. Tetapi dalam penelusuran dokumen sebelumnya sebagai pembanding bisa diperoleh sesuatu yang menimbulkan pendapat pemeriksa tersebut menjadi berbeda dari semula. Ini biasanya akan ditanggapi oleh orang yang mengajukan permintaan untuk memperbaiki klaimnya untuk mendefinisikan kembali penemuannya sebelum pemeriksaan lebih lanjut. Pada saat

\footnotetext{
${ }^{6}$ Kantor-IPB, Hak Kekayaan Intelektual dan Tantangan Implementasinya, Bogor, 2005
} 
mempertimbangkan apakah penemuan yang sedang diperiksa itu mengandung langkah inventif atau tidak, maka pemeriksa paten diperkenankan menggabungkan isi atau sebagian dari isi lebih dari satu dokumen yang sedang diperiksanya.

Penentuan nilai langkah inventif ini menjadi sangat subyektif artinya tergantung pada kemampuan dan ketrampilan seorang pemeriksa paten. Subyektifitas ini menjadi tidak berarti jika tidak ditunjang oleh kemampuan analisis pemeriksa, serta kelengkapan medan penelusurannya. Dikaitkan dengan penemuan dibidang kedirgantaraan, penemuan yang dihasilkan pada umumnya mengandung langkah inventif, mengingat bahwa batasan penemuan yang satu dengan yang lain sangat sedikit, namun telah menimbulkan perubahan fungsi secara keseluruhan, maka yang perlu ditentukan adalah tingkatan perubahan yang tidak dapat diduga terhadap penemuan tersebut, sehingga dapat dikategorikan sebagai langkah inventif. ${ }^{7}$

\section{Prosedur Permohonan Paten}

Prosedur permohonan paten menurut UU No.14 tahun 2001 meliputi tahap-tahap berikut ini yang intinya dilakukan melakukan prosedur sebagai berikut :
a) Pengajuan permohonan paten
b) Pemeriksaan persyaratan minimum
c) Pemeriksaan administratif
d) Pengumuman
e) Permohonan pemeriksaan substantif
f) Permohonan substantif
g) Keputusan pemberian atau penolakan permohonan paten

Secara skematik prosedur ini dapat dilihat dalam situs jaringan Ditjen HKI Kementerian Hukum dan Hak Asasi Manusia (http://www.dgip.go.id)

\section{Pemanfaatan Perlindungan Paten atas Hasil Litbangyasa}

Lembaga litbangyasa yang ingin mengajukan hasil litbangyasanya (invensi) untuk mendapatkan hak paten, ini harus menjadi perhatian pimpinan terkait mengingat salah satu ukuran kinerja riset adalah jumlah paten. Perlu diupayakan berbagai insentif

\footnotetext{
${ }^{7}$ Puskatek, Penerapan HKI Terhadap Hasil Litbangyasa, Balai Besar, dan Baristand Industri, Laporan Akhir
} 
dan jenis penghargaan sebagai daya tarik dalam meningkatkan penelitian menuju diperolehnya hak paten. ${ }^{8}$

Salah satu indikator keberhasilan litbangyasa adalah jumlah output yang dihasilkan dari aktivitas itu, output litbangyasa dapat berupa publikasi ilmiah, paten, model, prototype dan sebagainya. Saat ini, menurut beberapa laporan yang dipublikasikan jumlah jurnal ilmiah, terutama jurnal internasional dan paten yang dihasilkan peneliti dan perekayasa di Indonesia masih tergolong rendah jika dibandingkan dengan beberapa Negara tetangga. Belum lagi jika output litbangyasa yang ditindaklanjuti menjadi produk yang didifusikan ke masyarakat atau dikomersialisasikan oleh industri angkanya lebih rendah lagi. Padahal, sesuai amanat UUD 1945, IPTEK didedikasikan untuk kesejahteraan rakyat. Oleh karena itu, IPTEK termasuk teknologi produk litbangyasa diarahkan untuk berkontribusi bagi perekonomian yang akan mendorong peningkatan kesejahteraan masyarakat.

Alasan utama mendaftarkan paten ialah untuk mencegah digunakannya paten oleh pihak lain selain merupakan kebijakan instansi. Kesadaran pentingnya perlindungan paten, apabila patennya dilanggar oleh pihak lain, karena tindakan tersebut bertentangan dengan peraturan perundang-undangan dan menyadari bahwa litbangyasa merupakan hasil kreativitas yang menghabiskan tenaga, waktu dan biaya.

Selanjutnya mengenai pengalihan hak paten yang dihasilkan oleh litbangyasa industri dapat dialihkan ke pihak lain dengan imbalan royalty. Salah satu alasan melakukan suatu penelitian/pengembangan/rekayasa untuk memenuhi kebutuhan masyarakat industry teknologi, jauh diatas pilihan lain yaitu karena tugas pokok dan memenuhi angka kredit tugas dari atasan serta untuk meningkatkan kesadaran peneliti akan fungsi mereka.

\section{Kesimpulan dan Saran}

\section{Kesimpulan}

Indonesia yang saat ini sedang menjalankan program-program pembangunan akan mengalami banyak penemuan atau inovasi-inovasi yang signifikan.

\footnotetext{
${ }^{8}$ Eddy herjanto, Pemahaman dan Penerapan Paten dibalai Litbangyasa Industri, Pusat Penelitian dan Pengkajian Teknologi Industri dan Hak Kekayaan Intelektual, 2010
} 
Adanya usaha-usaha pemahaman pentingnya pendaftaran hak kekayaan intelektual atas hasil-hasil penelitian di lembaga penelitian dan pengembangan dalam upaya melindungi hak kekayaan intelektual para penelitinya dengan mendaftarkan penemuan mereka.

\section{Saran}

Dari hasil analisis, disarankan perlunya beberapa hal sebagai berikut : Pertama, Disusunnya pola pembinaan pemahaman dan penguasaan HKI bagi para peneliti/perekayasa yang lebih komprehensif. Kedua, disusunnya mekanisme pembagian royalti paten yang lebih menarik dalam merangsang dihasilkannya invensi yang prospektif dipatenkan dan atau penghargaan yang signifikan atas penelitian yang laku komersial. 


\section{Daftar Pustaka}

Ditjen HKI, Prosedur Permohonan Paten http://www.dgip.go.id/ ebscript/ publicportal.cgi, diakses 9 Nov 2015

Eddy herjanto, Pemahaman dan Penerapan Paten dibalai Litbangyasa Industri, Pusat Penelitian dan Pengkajian Teknologi Industri dan Hak Kekayaan Intelektual, 2010

European Patent Office, Intellectual Property Watch, http://www.ipwatch.org/ weblog.epo_looks_to_future_technologies_leadership_change diakses 9 Nov 2015

Kantor-IPB, Hak Kekayaan Intelektual dan Tantangan Implementasinya, Bogor, 2005

Puskatek, Penerapan HKI Terhadap Hasil Litbangyasa, Balai Besar, dan Baristand Industri, Laporan Akhir

Undang-Undang Republik Indonesia Nomor 14 Tahun 2001 Tentang Paten

Web.mit.edu/ipc/www/pubs/articles/chakrabarti.pdf

www.ristek.go.id/indexphp/module/news diakses 13 Nov 2015 